Journal of Animal and Veterinary Advances $10(6): 715-722,2011$

ISSN: $1680-5593$

(C) Medwell Journals, 2011

\title{
Study of the Amplification Capacity of A Two-Temperature PCR and its Application in Bovine Sex Identification
}

\author{
${ }^{1}$ Dong Wang, ${ }^{1} \mathrm{Bo}$ Lin, ${ }^{1}$ Huabin Zhu, ${ }^{1}$ Haisheng Hao, ${ }^{2}$ Chengjiang Wu, \\ ${ }^{1}$ Weihua Du and ${ }^{1}$ Xueming Zhao \\ ${ }^{1}$ The Key Laboratory for Farm Animal Genetic Resources and \\ Utilization of Ministry of Agriculture of China, Institute of Animal Sciences, \\ Chinese Academy of Agricultural Sciences, 100193 Beijing, China \\ ${ }^{2}$ Jilin Agriculture University, 130118 Changchun, China
}

\begin{abstract}
To study the amplification potential and establish a two-temperature PCR sex identification method, DNA templates prepared from bovine blood, sperm and hair follicles were amplified through two-temperature PCR in this study. Fragments from 207-1413 bp could be amplified successfully while fragments of 1500 bp in length could not be amplified. In further studies we found that an extension step was necessary to amplify longer fragments and as the extension time decreased, the denaturation and annealing times were increased. After optimization we found the best two-temperature PCR to be a reaction using $1.0 \mathrm{mmol} \mathrm{L}{ }^{-1} \mathrm{Mg}^{2+}, 1.0 \mathrm{unit}^{2}$ polymerase and 30 cycles. The amplification results using different equipment and Taq polymerases indicated that the two-temperature PCR can be used for any fragment equal to or $<1413$ bp with any common Taq polymerase. The kinetic rate of the polymerase was determined to be the factor limiting the amplification length and rate. Additionally, the PCR timing was shortened from 1.5-2.0 h to 30-38 min with the two-temperature PCR. The sex identification of bovine blood, fibroblasts and blastmeres were carried out by turns using this rapid PCR and a rapid sex identification method of cattle embryo was establishment. Both amplification time and cost were saved greatly with this method and we found that the two-temperature PCR was sensitive and fast enough for widespread use in many research areas such as genetics, sex identification, forensics and clinical medicine.
\end{abstract}

Key words: Bovine, rapid PCR, sex identification, two-temperature PCR, sensitive, genetics

\section{INTRODUCTION}

Polymerase Chain Reaction (PCR) has been widely used for sex identification, especially in the field of bovine embryo transfer (Manna et al., 2003; Ekici et al., 2006; $\mathrm{Lu}$ et al., 2007). Some PCR methods were explored, including Primer Extension Preamplification-PCR (PEP-PCR) and nested PCR (Tominaga, 2004; Mapletoft and Hasler, 2005; Fu et al., 2007). With these PCR methods, the stress reaction of the embryo outside the body is increased due to the longer amplification time. Though, the amplification time was markedly shortened after the Lamp method was invented (Zhang et al., 2009), the false positive rates caused by contamination were problematic. Therefore, it is important to develop a rapid, sensitive and cost-effective PCR method for bovine sex identification.

Amplification times in PCR have been shortened greatly through polymerase studies (Mullis and Faloona, 1987; Angers et al., 2001; Wang et al., 2004).
Additionally, a variety of PCR machines with high thermal transfer efficiency have been invented such as infrared heated PCR systems (Easley et al., 2006), shuttle PCR devices and Continuous-Flow Polymerase Chain Reaction (CF-PCR) instrumentation (Hashimoto et al., 2004; Chen et al., 2008). However, as the amplification efficiency increases, the cost of these special devices and the tendency of contamination increase.

In addition to the thermal transfer capability of the cycling instrument, the extension capacity of DNA polymerase is another key factor affecting PCR amplification efficiency. Innis et al. (1988) obtained an extension rate of $60.4\left(\mathrm{nt} \mathrm{sec}^{-1}\right.$ ) at $70^{\circ} \mathrm{C}$ (Innis et al., 1988). It was reported that the Taq polymerase showed an excellent extension activity and the amplification could be finished during the heating ramp (Benter et al., 1995). So, the Taq polymerase is more popularly used than Pyrococcus furiosus exo-DNA polymerase and Sequenase 2.0 (Angers et al., 2001). A 74 bp fragment was first successfully amplified using Taq polymerase with

Corresponding Author: Dong Wang, The Key Laboratory for Farm Animal Genetic Resources and Utilization of Ministry of Agriculture of China, Institute of Animal Sciences, Chinese Academy of Agricultural Sciences, 100193 Beijing, China 
two-temperature PCR (Cha et al., 1992). Wittwer amplified a $536 \mathrm{bp}$ fragment of human $\beta$-globin with $30 \mathrm{sec}$ cycles of rapid PCR but the extension rate was only about $36 \mathrm{nt} \mathrm{sec}{ }^{-1}$. So, they pointed out that primer extension was not instantaneous, the time required for elongation depended on the length of the amplicon. What is more, the time became the limiting factor for PCR with very short cycle (Wittwer et al., 1990). It was believed that the polymerization rate of Taq polymerase is $\sim 33 \mathrm{nt} \mathrm{sec}{ }^{-1}$ at the optimal temperature and the extension time should be $1 \mathrm{~min}$ for each $1000 \mathrm{bp}$ fragment (Sambrook and Russsell, 2001). The sequence length and extension time are crucial for the amplification yield of Taq polymerase, the amplification yield of 297 bp amplicon by rapid PCR with $10 \mathrm{sec}$ extension time is $<45.3 \%$ of the theoretical yield, the better amplification result for $600 \mathrm{bp}$ amplicon was obtained with $30 \mathrm{sec}$ extension time while the yield with $12 \mathrm{sec}$ extension time is only $36.8 \%$ of the theoretical yield.

These evidences demonstrated the extension time should be lengthened as the length of fragment sequence increases (Whitney et al., 2004). Thereafter, few studies about the two-temperature PCR were reported. The detection of the respiratory virus and the human PPARG gene demonstrated once more the high sensitivity and efficiency of the two-temperature PCR for fragments equal to or $<717$ bp (Lam et al., 2007; http://tools. invitrogen. $\mathrm{com} /$ content $/ \mathrm{sfs} /$ brochures/cms 040563. pdf). In their study, special equipment and reagents for rapid PCR were used, the Applied Biosystems 9800 Fast PCR System and the GeneAmp Fast PCR Master Mix are essential (Applied Biosystems, CA). However, the components of the Master Mix were not provided and the potential amplification capacity of the fast PCR system was not shown. Furthermore, it was not showed if the rapid PCR depends on the properties of the Taq polymerase or the special reagents and equipment (Lam et al., 2007) and no experiments showed whether fast DNA amplification can be obtained using common equipment and reagents. Exploring the amplification potential may play a very important role in rapid sex determination and other genetic detection areas.

Therefore, we investigated the amplification potential of the two-temperature PCR method and set up a rapid PCR detection technique using common equipment and reagents, provided an alternative of current rapid PCR systems involved expensive devices and reagents. In this study, two-temperature PCR was used to amplify DNA fragments longer than 200 bp using common PCR controls. Longer fragments were amplified until no PCR results were detected. The factors crucial to rapid PCR was investigated and optimized as were the effects of different kinds of Taq polymerase and PCR cycler. Finally, the application of this method to sex identification of the blood, fibroblast and blastmere was also demonstrated.

\section{MATERIALS AND METHODS}

Enzymes: Taq DNA Polymerase ${ }^{\circledR}\left(20 \mathrm{mmol} \mathrm{L}^{-1}\right.$ Tris-HCl

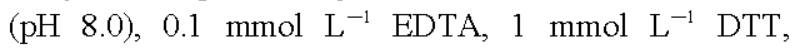
$100 \mathrm{mmol} \mathrm{L}^{-1} \mathrm{KCl}$ and 50\% glycerol; Lot: H6721) and Taq reaction buffer $\left(10 \mathrm{x} ; 200 \mathrm{mmol} \mathrm{L}^{-1}\right.$ Tris- $\mathrm{HCl}(\mathrm{pH} 8.4)$, $200 \mathrm{mmol} \mathrm{L}^{-1} \mathrm{KCl}, 100 \mathrm{mmol} \mathrm{L}^{-1}\left(\mathrm{NH}_{4}\right) 2 \mathrm{SO}_{4}$ and $15 \mathrm{mmol}$ $\mathrm{L}^{-1} \mathrm{MgCl}_{2}$; Lot: H6512) were purchased from Tiangen Co. (Beijing, China). To investigate the effect of different Taq polymerase products on the two-temperature PCR, other polymerases and reaction buffers were purchased from the following companies: Takara, Taq polymerase ${ }^{\circledR}$ $\left(100 \mathrm{mmol} \mathrm{L}^{-1}\right.$ Tris-HCl, $500 \mathrm{mmol} \mathrm{L}^{-1} \mathrm{KCl}$ and $15 \mathrm{mmol}$ $\left.\mathrm{L}^{-1} \mathrm{MgCl}_{2}\right)$ and $10 \times$ buffer $\left(200 \mathrm{mmol} \mathrm{L}^{-1}\right.$ Tris-HCl (pH 8.4), $200 \mathrm{mmol} \mathrm{L}{ }^{-1} \mathrm{Kcl}, 100 \mathrm{mmol} \mathrm{L} \mathrm{L}^{-1}\left(\mathrm{NH}_{4}\right)$ $2 \mathrm{SO}_{4}$ and $15 \mathrm{mmol} \mathrm{L} \mathrm{L}^{-1} \mathrm{MgCl}_{2}$ ); Dongsheng, Taq polymerase $^{\circledR}\left(20 \mathrm{mmol} \mathrm{L}^{-1}\right.$ Tris- $\mathrm{HCl}, 0.1 \mathrm{mmol} \mathrm{L}^{-1} \mathrm{EDTA}$, $1 \mathrm{mmol} \mathrm{L}^{-1} \mathrm{DTT}, 100 \mathrm{mmol} \mathrm{L}^{-1} \mathrm{KCl}, 50 \%$ glycerol and $1 \%$ Triton X-100) and $10 \times$ buffer $\left(500 \mathrm{mmol} \mathrm{L}^{-1} \mathrm{KCl}, 100 \mathrm{mmol}\right.$ $\mathrm{L}^{-1}$ Tris- $\mathrm{HCl}$ and $15 \mathrm{mmol} \mathrm{L}^{-1} \mathrm{MgCl}_{2}$ ) and Dingguo Company, Taqpolymeras $\mathrm{e}^{\circledR}\left(50 \mathrm{mmol} \mathrm{L}^{-1}\right.$ Tris- $\mathrm{HCl}, 1 \mathrm{mmol}$ $\mathrm{L}^{-1} \mathrm{DTT}, 0.1 \mathrm{mmol} \mathrm{L}{ }^{-1}$ EDTA, $100 \mathrm{mmol} \mathrm{L}^{-1} \mathrm{KCl}, 1 \%$ Triton X-100 and 50\% glycerol (pH 8.0) ) and $10 \times$ buffer (100 mmol L $\mathrm{m}^{-1}$ Tris- $\mathrm{HCl}, 100 \mathrm{mmol} \mathrm{L}^{-1}\left(\mathrm{NH}_{4}\right) 2 \mathrm{SO}_{4}, 100$ mmol L ${ }^{-1} \mathrm{KCl}$ and $1 \%$ Triton $\mathrm{X}-100(\mathrm{pH} 8.8)$ ).

PCR equipment: Instead of using expensive equipment specifically designed for rapid PCR the researchers used the following common commercial equipment for the two-temperature PCR: a Mastercycler ${ }^{\circledR}$ (Eppendorf) and a Thermal Cycler TC-3000 ${ }^{\circledR}$ (Techne). The heating rate was $3^{\circ} \mathrm{C} \mathrm{sec}^{-1}$ for the Mastercycler and $3.6^{\circ} \mathrm{C} \mathrm{sec}{ }^{-1}$ for the TC-3000.

DNA preparation: DNA templates were prepared from bovine blood, hair follicles and sperm samples. An anticoagulant blood sample $(100 \mu \mathrm{L})$ was fully mixed with $900 \mu \mathrm{L}$ of $\mathrm{ddH}_{2} \mathrm{O}$. After a $10 \mathrm{~min}$ incubation in an ice bath, the mixture was centrifuged at $13000 \mathrm{~g}$ for about $1 \mathrm{~min}$. The supernatant was discarded and the pellet was washed once with $\mathrm{ddH}_{2} \mathrm{O}$. Next, $120 \mu \mathrm{L}$ of $\mathrm{ddH}_{2} \mathrm{O}$ was added and mixed with the pellet, after which the sample tube was boiled for $10 \mathrm{~min}$. This mixture was cooled in an ice bath for $5 \mathrm{~min}$ and recentrifuged for $5 \mathrm{~min}$. Then the supernatant was extracted. The supernatant was either used immediately in the PCR reaction or stored at $-20^{\circ} \mathrm{C}$ for future use.

The hair follicle sample was mixed with $20 \mu \mathrm{L}$ of Proteinase $\mathrm{K}$ lysate and incubated at $65^{\circ} \mathrm{C}$ for $30 \mathrm{~min}$ then $95^{\circ} \mathrm{C}$ for $15 \mathrm{~min}$ and $4^{\circ} \mathrm{C}$ for $10 \mathrm{~min}$. The mixture was centrifuged and the supernatant was used in the PCR reaction immediately or stored at $-20^{\circ} \mathrm{C}$ for future use. 
About $1 \mu \mathrm{L}$ of semen sample (about 30000 sperm) was fully mixed with $200 \mu \mathrm{L}$ of $\mathrm{ddH}_{2} \mathrm{O}$ and then centrifuged at $13000 \mathrm{~g}$ for $2 \mathrm{~min}$. After the supernatant was discarded, $100 \mu \mathrm{L}$ of alkaline lysis buffer $(100 \mu \mathrm{L} 10 \times \mathrm{PCR}$ buffer, $20 \mu \mathrm{L} \mathrm{MgCl}_{2}, 10 \mu \mathrm{L}$ protease and $870 \mu \mathrm{L} \mathrm{ddH}_{2} \mathrm{O}$ ) was added to the pellet and the sample was then incubated at $65^{\circ} \mathrm{C}$ for $15 \mathrm{~min}$. Finally, $100 \mu \mathrm{L}$ of neutralizer fluid $\left(900 \mathrm{mmol} \mathrm{L}{ }^{-1}\right.$ Tris- $\mathrm{HCl}(\mathrm{pH}=8.3)$ ) was added to inactivate the reaction. The mixture was then centrifuged at $13,000 \mathrm{~g}$ for about $1 \mathrm{~min}$. The supernatant was then immediately used in the PCR reaction or stored at $-20^{\circ} \mathrm{C}$ for future use.

Design and synthesis of primers: Primer C34 was designed with Oligo 6.0, according to the gene sequence of bovine chromosome 2 (gi: 119951937). Primers Y34, Y56 and Y684 were designed according to the sequence of the SRY bovine gene (gi: 4878004). Primer 923 was designed according to the MYF5 bovine gene (gi: 281335) and primer 1371 was designed according to the MSTN bovine gene (gi: AB076403).

The rest of the primers were designed according to the gene sequence of bovine euchromosome 3 (gi: 119890289). Primer information is shown in Table 1. All primers were synthesized by Invitrogen Company (Shanghai, China).

PCR procedures: Unless otherwise noted, all fragments were amplified using an Eppendorf Mastercycler and a control PCR program: preheating at $94^{\circ} \mathrm{C}$ for $5 \mathrm{~min}$, cycling for 30 cycles and extending at $72^{\circ} \mathrm{C}$ for $8 \mathrm{~min}$. Each cycle consisted of a denaturation step for $45 \mathrm{sec}$ at $94^{\circ} \mathrm{C}$, an annealing step for $30 \mathrm{sec}$ at the temperature shown in Table 1 and an extension step for $1 \mathrm{~min}$ at $72^{\circ} \mathrm{C}$. The two-temperature PCR program was as follows: preheating at $94^{\circ} \mathrm{C}$ for $30 \mathrm{sec}$, cycling for 30 cycles and extending at $72^{\circ} \mathrm{C}$ for $1 \mathrm{~min}$.

Each cycle consisted of a denaturation step for $1 \mathrm{sec}$ at $94^{\circ} \mathrm{C}$ and an annealing step for $1 \mathrm{sec}$ at the temperature shown in Table 1. PCR products longer than 1000 bp were analyzed by $1 \%$ agarose gel electrophoresis while other products shorter than $1000 \mathrm{bp}$ were analyzed by $2 \%$ agarose gel electrophoresis.

The optimization and analysis of different factors: After different fragments were amplified with the two-temperature PCR, the effects of the concentration of $\mathrm{Mg}^{2+}$, the amount of Taq DNA polymerase and the number of cycles were assessed. The results were used to determine the two-temperature PCR program that could efficiently amplify DNA fragments range in length in minimal time.

\begin{tabular}{|c|c|c|c|}
\hline Name & Sequences & $\begin{array}{l}\text { Melting } \\
\text { temperature } \\
\left({ }^{\circ} \mathrm{C}\right)\end{array}$ & $\begin{array}{l}\text { Length } \\
\text { (bp) }\end{array}$ \\
\hline \multirow[t]{2}{*}{$\mathrm{C} 34$} & F:TTGCTGCTCTTGCCTTTGCTT & 62.0 & 207 \\
\hline & R:GTCCACCTGCCACAACTAAAT & 62.0 & \\
\hline \multirow[t]{2}{*}{ Y34 } & F:CGCCTTCATTGTGTGGTCTC & 62.0 & 402 \\
\hline & R:CTGCTGTGATGCTCCTTTTG & 60.0 & \\
\hline \multirow[t]{2}{*}{ Y56 } & F:TTGACCGACGATGTTTACAG & 58.0 & 503 \\
\hline & R:GGCTTTCCATTTGTGAGTAT & 56.0 & \\
\hline \multirow[t]{2}{*}{ Y684 } & F:TCCGCTATGTTCAGAGTATT & 56.0 & 684 \\
\hline & R:TAAGCACAAGAAAGTCCAGG & 58.0 & \\
\hline \multirow[t]{2}{*}{ G923 } & F:ATATGCCACGGATAAAAGC & 58.0 & 923 \\
\hline & R:GCGAGATGCTATTCAGATTT & 58.0 & \\
\hline \multirow[t]{2}{*}{ G1371 } & F:GCTCCCAGACCTTACCCCAA & 72.3 & 1371 \\
\hline & R:CACAGCCCCTCTTTTTCCAC & 70.3 & \\
\hline \multirow[t]{2}{*}{ G1413 } & F:ATGGTGAAGGTCGGAGTGAACGG & 72.0 & 1413 \\
\hline & R:AAAGGGCAAGAGCAAAGGTCAGCA & 72.0 & \\
\hline \multirow[t]{2}{*}{ G1500 } & F:TCCTTCCTTAGCCTTGCCGTCTTT & 72.0 & 1500 \\
\hline & R:CCTTGACTGTGCCGTTGAACT & 74.0 & \\
\hline
\end{tabular}

Sex identification with rapid PCR: Sex identification from blood, fibroblast and blastmere samples for both male and female Holstein bovines was carried out using two-temperature PCR. For great difference in the length between the amplicons will help to the rapid sex identification, the primer Y56 for 503 bp fragment of sex-specific Sry gene and primer G1371 for $1371 \mathrm{bp}$ internal fragment of Myostatin gene were used in the duplex PCR system. The sensitivity of the two-temperature PCR was determined using two template groups, one using 1 cell and the other using 5 cells.

The cultured fibroblast was centrifuged then the cell pellet was washed with PBS and adjust cell concentration to $1 \times 10^{3}$ cells $\mathrm{mL}^{-1}$. Under the microscope, the fibroblast were separated using suctionpipe in 1 cell or 5 cells each time, the separated fibroblast were transferred into different centrifuge tube labeled with cell number and the sex, respectively.

Then the cloned cattle embryos from fibroblast were identified. Embryos after cultured 7 days were washed 3 times in sterile $0.2 \mathrm{M}$ saccharose PBS containing no bovine serum albumin to avoid the potential contamination of bovine DNA in Bovine Serum Albumin (BSA). Each embryo were placed in a disposable, plastic Petri dish with $0.4 \mathrm{~mL} 0.2 \mathrm{M}$ saccharose PBS, the splitting was carried out using a $\times 120$ stereomicroscope and a micromanipulator with a metal microblade. The 1 and 3 blastomeres were biopsied from trophectoderm of each blastocysts and were transferred to the PCR tube and labeled for sex identification, respectively while the embryo was returned to culture.

A $20 \mu \mathrm{L}$ PCR reaction was performed for sexing, firstly with blood DNA samples and different number of fibroblast samples then with different number of blastmeres of the cloned embryos. Each reaction system included $2 \mu \mathrm{L}$ of $10 \times \mathrm{PCR}$ buffer, $0.35 \mu \mathrm{L}$ of $62.5 \mathrm{mmol} \mathrm{L}^{-1}$ 
$\mathrm{Mg}^{+2}+, 2 \mu \mathrm{L}$ DNA template (or fibroblast or blastmere), $0.4 \mu \mathrm{L}$ of $2.5 \mathrm{U} \mu \mathrm{L}^{-1}$ Taq DNA polymerase, $2.25 \mu \mathrm{L}$ of $2 \mu \mathrm{mol} \mu \mathrm{L}^{-1}$ primer $\mathrm{Y} 56,2.25 \mu \mathrm{L}$ of $2 \mu \mathrm{mol} \mu \mathrm{L}^{-1}$ primer G1371, $4 \mu \mathrm{L}$ of $1 \mathrm{mmol} \mathrm{L}^{-1} \mathrm{dNTP}$ and $6.75 \mu \mathrm{L} \mathrm{ddH} 2 \mathrm{O}$. The two-temperature PCR cycle program was as follows: $94^{\circ} \mathrm{C}$ for $30 \mathrm{sec}$ followed by 30 cycles of $94^{\circ} \mathrm{C}$ for $1 \mathrm{sec}, 55^{\circ} \mathrm{C}$ for $1 \mathrm{sec}$ and then a final $1 \mathrm{~min}$ extension at $72^{\circ} \mathrm{C}$. At the same time, the control PCR program was used to amplify the blood DNA samples, the parameter was described in section 2.5. The PCR products were detected with 1.5\% agarose gel electrophoresis and the amplification time was recorded at once.

\section{RESULTS AND DISCUSSION}

The amplification capacity of two-temperature PCR: In order to determine the amplification capacity of the two-temperature PCR, DNA fragments of different lengths were amplified; the length was increased until no product could be detected. A common PCR was performed as control to confirm the feasibility of the two-temperature program. To elucidate the application of the two-temperature PCR, DNA templates from blood, sperm and hair follicle were amplified. As shown in Fig. 1 for

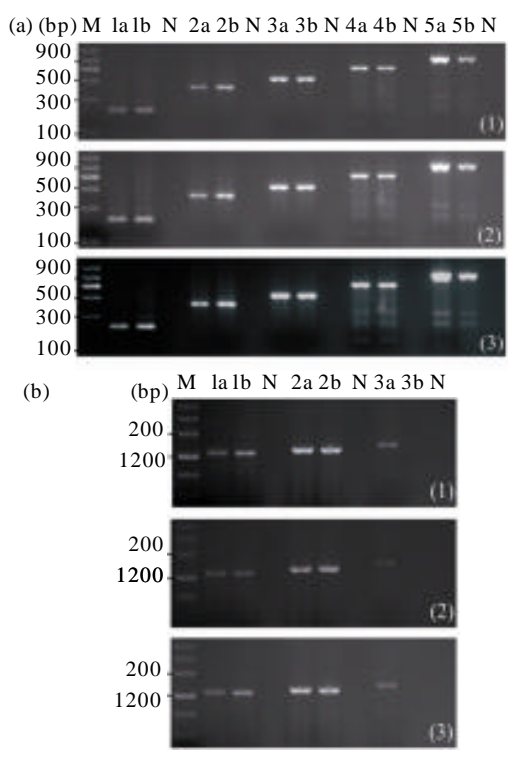

Fig. 1: Comparison of the amplification results of 208-1500 bp fragments from (1) blood, (2) hair follicle and (3) sperm DNA templates $\mathrm{M}$ : DNA marker. N: Negative control. Lanes na are fragments amplified with common cycling PCR and lanes nb are fragments amplified with two-temperature PCR. Lanes 1-5 in (A): 207, 402, 503, 684 and 923 bp fragments, respectively. Lanes 1-3 in (B): 1371 , 1413 and $1500 \mathrm{bp}$ fragments, respectively fragments $<1500 \mathrm{bp}$, the bands obtained with two-temperature PCR were as clear as those obtained through the common program. This result indicates that the two-temperature PCR efficiently amplified DNA fragments from 207-1413 bp. It took 38 and $120 \mathrm{~min}$, respectively for the two-temperature $\mathrm{PCR}$ and common PCR to finish the entire amplification process; furthermore, $1500 \mathrm{bp}$ fragments was only amplified by the common PCR program.

The above result implied that the extension stage is very important for the amplification of fragments longer than $1413 \mathrm{bp}$. In order to obtain the amplification products of $1500 \mathrm{bp}$ DNA sequence, the common PCR program was modified, the extension duration was shortened from $60-20 \mathrm{sec}^{-1}$ while the time for denaturation and annealing were set at $15,10,5$ and $1 \mathrm{sec}$, respectively (Table 2). Interestingly as showed in Fig. 2, the running time of denaturation and annealing influenced the lasting of the extension. Therefore, the extension time could be reduced when the time for denaturation and annealing was increased.

Optimization of the two-temperature PCR method: As shown in Fig. 3 , the best PCR results were obtained when the concentration of $\mathrm{Mg}^{2+}$ was set as $1.0 \mathrm{mmol} \mathrm{L}^{-1}$, the

Table 2: Different durations of the denaturation, annealing and extension stages for the amplification of $1500 \mathrm{bp}$ fragments

\begin{tabular}{lccc}
\hline Lanes & Denaturation $(\mathrm{sec})$ & Annealing $(\mathrm{sec})$ & Extension $(\mathrm{sec})$ \\
\hline 1 & 15 & 15 & 50 \\
2 & 15 & 15 & 40 \\
3 & 15 & 15 & 35 \\
4 & 15 & 15 & $30(/)$ \\
5 & 15 & 15 & $20(/)$ \\
6 & 10 & 10 & 50 \\
7 & 10 & 10 & 40 \\
8 & 10 & 10 & $35(/)$ \\
9 & 10 & 10 & $30(/)$ \\
10 & 5 & 5 & 60 \\
11 & 5 & 5 & 55 \\
12 & 5 & 5 & $50(/)$ \\
13 & 5 & 5 & $40(/)$ \\
14 & 1 & 1 & 60 \\
15 & 1 & 1 & $55(/)$ \\
\hline
\end{tabular}

(/): no band observed

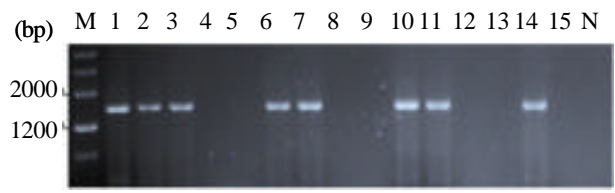

Fig. 2: Amplification results of the $1500 \mathrm{bp}$ fragment using a blood DNA template M: DNA marker N: Negative control. Lanes 1-15: 1500 bp fragment amplified with different denaturation, annealing and extension times as shown in Table 2 


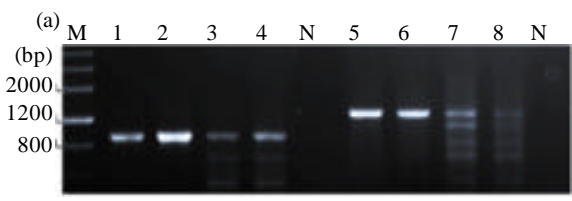

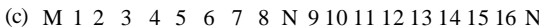

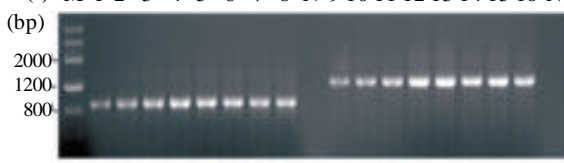

(b) $\begin{array}{lllllllllllllll}M & 1 & 2 & 3 & 4 & \mathrm{~N} & 5 & 6 & 7 & 8 & \mathrm{~N}\end{array}$

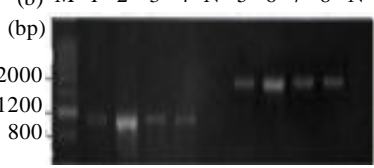

(d) M la lb N 2a $2 b \quad \mathrm{~N} 3 \mathrm{a} 3 \mathrm{~b} N$

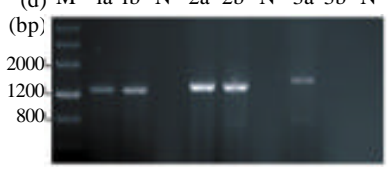

Fig. 3: Optimization of the $\mathrm{Mg}^{2+}$ concentration (a) the Taq polymerase concentration (b) and number of cycles (c) and amplification results when using the optimized conditions (d) for the amplification of a blood DNA template M: DNA marker. N: negative control. a) Lanes 1-4: A $923 \mathrm{bp}$ fragment amplified with $\mathrm{Mg}^{2+}$ concentrations of $0.5,1.0$, 1.5 or $2.0 \mathrm{mmol} \mathrm{L}^{-1}$, respectively. Lanes 5-8: A $1371 \mathrm{bp}$ fragment amplified with $\mathrm{Mg}^{2+}$ concentrations of $0.5,1.0$, 1.5 or $2.0 \mathrm{mmol} \mathrm{L} \mathrm{mmol} \mathrm{L}{ }^{-1}$, respectively. b) Lanes 1-4: A $923 \mathrm{bp}$ fragment amplified with $0.5,1.0,1.5$ or 2.0 units of Taq polymerase, respectively; Lanes 5-8: A $1371 \mathrm{bp}$ fragment amplified with $0.5,1.0,1.5$ or 2.0 units of Taq polymerase, respectively. c) Lanes 1-8: A 923 bp fragment amplified for 24, 26, 28, 30, 32, 34, 36 or 38 cycles, respectively. Lanes 9-16: A 1371 bp fragment amplified for $24,26,28,30,32,34,36$ or 38 cycles, respectively. d): Lanes 1-3: 1371, 1413, $1500 \mathrm{bp}$ fragments, respectively. Lanes na show fragments amplified using the common cycling PCR. Lanes nb show fragments amplified with the two-temperature PCR

PCR product declined as well as a series of non-specific amplification bands appeared when $\mathrm{Mg}^{2+}$ concentration

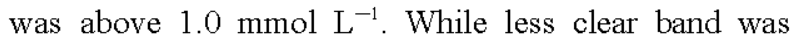
detected when $0.5 \mathrm{mmol} \mathrm{L}{ }^{-1} \mathrm{Mg}^{2+}$ was used. As showed in Fig. 3, clear bands were obtained after two-temperature PCR reaction using 1.0 unit polymerase. The amplification yield was less by PCR reaction with 1.5 and 2.0 units of polymerase. Figure 3 shows that a much clearer band was obtained with PCR reaction of 30 cycles. Beyond 30 cycles, the brightness of the bands did not increase. In order to determine whether the failure of the $1500 \mathrm{bp}$ fragment amplification was related to the PCR or to the amplification capacity of the two-temperature PCR, the $1500 \mathrm{bp}$ fragment and other fragments were amplified using optimized conditions in both the common and the two-temperature PCRs. As showed in Fig. 3, under optimized two-temperature PCR conditions, clear bands were only obtained for fragments shorter than $1500 \mathrm{bp}$, no bands detected for $1500 \mathrm{bp}$ fragment.

A comparison of polymerases and equipment: To study whether different Taq polymerase differently impact the two-temperature PCR process, Taq DNA polymerase products from 4 different companies were used in the two-temperature PCR. As shown in Fig. 4, the 923 and $1371 \mathrm{bp}$ fragments were successfully amplified with Taq polymerases from Tiangen, Takara, Dongsheng and Dingguo. A TC-3000 Thermal Cycler with a heating/cooling rate up to $3.6^{\circ} \mathrm{C} \mathrm{sec}$ was used, compared parameters to the Eppendorf Mastercycler. The amplification results in Fig. 4 show that ideal amplification

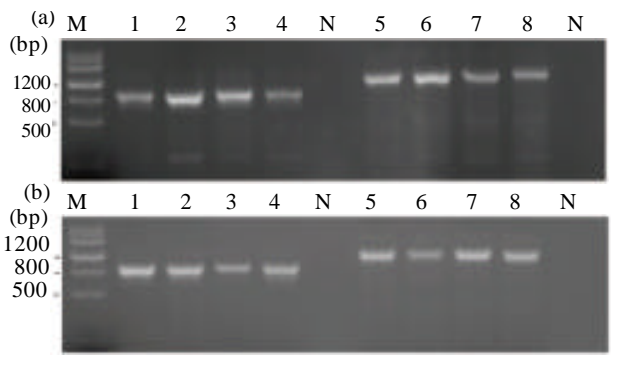

Fig. 4: Amplification results for 923 and 1371 bp fragments using a blood DNA template and different equipment and Taq DNA polymerases. a: Amplification results using the Eppendorf Mastercycler and b: Amplification results using the TC-3000 Thermal Cycler. M: DNA marker. N: negative control. Lanes 1-4: A 923 bp fragment amplified with Taq polymerases from Tiangen, Takara, Dongsheng or Dingguo Co., respectively. Lanes 5-8: A 1371 bp fragment amplified with Taq polymerases from Tiangen, Takara, Dongsheng or Dingguo Co., respectively

results were obtained with the two different types of PCR machines. It took around $30 \mathrm{~min}$ to finish the whole amplification procedure with the TC-3000 Thermal Cycler.

Application of the two-temperature PCR method: To demonstrate the potential use of two-temperature PCR, the sex identification of bovines was conducted with two-temperature $\mathrm{PCR}$ using blood samples. The Y 


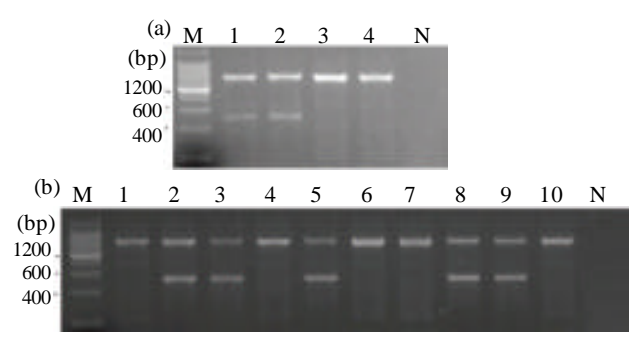

Fig. 5: The sex identification results using the two-temperature duplex PCR for the $503 \mathrm{bp}$ (Sry) and $1371 \mathrm{bp}$ (Myostatin) fragments in bovine blood samples (a) and the sensitivity of the sex identification method using the fibroblast DNA template (b). M: DNA marker. N: negative control. (a) Lanes 1 and 2 are blood from a male and lanes 3 and 4 are blood from a female. (b) Lanes 1 and 2 are blood samples from a female and a male using control PCR program, respectively Lanes 3-6: single cells. Lanes 7-10: five cells. Lanes 1, 4, 6, 7, and 10 are from females and Lanes 2, 3, 5, 8, 9 are from males

chromosome specific primer Y56 and the internal primer G1371 were used in this duplex PCR system. The sexing shown in Fig. 5 showed that all samples had clear bands, the identified results were all consistent with the known sex of the animals. Furthermore, it took $30 \mathrm{~min}$ to finish the PCR amplification using the TC-3000 Thermal Cycler while it took $38 \mathrm{~min}$ for the Eppendorf Mastercycler.

After the one and five-cell templates were amplified using this duplex two-temperature PCR, clear, bright and exact amplification results were obtained from both groups. As expected, two bands were obtained in all male samples and one band was obtained in all female samples. The ideal identification results shown in Fig. 5 imply that the specificity could be increased by removing the extension step and shortening the annealing step. About 10 cloned embryos were biopsied and 1 and 3 blastmeres were sampled from each embryo separately. The identification results with this rapid PCR were shown in Fig. 6 and the clear and bright bands indicated that the ideal results were obtained from all embryos. The same identification results were obtained from both blastmere number groups and they are all consistent with the known sex of the cloned embryos.

Exploring of the extension capacity of the Taq polymerase is the key of rapid PCR: The optimal extension temperature for Taq polymerase is variable, it changes between 70 and $79^{\circ} \mathrm{C}$, depending on specific PCR system

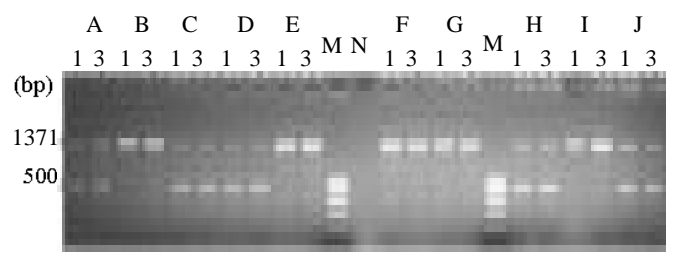

Fig. 6: The sex identification results using the two-temperature duplex PCR for the 503 and $1371 \mathrm{bp}$ fragments in cloned bovine embryos $\mathrm{M}$ : DNA marker from 100- $600 \mathrm{bp}$. N: negative control in saccharose PBS. The letters from A-J represent different cloned embryos, the number 1 represents the sex identification results of samples in 1 blastmere while 3 represents the sex identification results of samples in 3 blastmeres. Embryo A, C, D, $\mathrm{H}, \mathrm{J}$ are males and embryo B, E, F, G, I are females

used (Innis et al., 1988; Wittwer and Garling, 1991; Sambrook and Russell, 2001). Correspondingly, the extension rate was also different from 33.3-60.4 $\mathrm{nt} \mathrm{sec}^{-1}$, according to the extension temperature applied. In the previous study we obtained an extension rate of $191 \mathrm{nt} \mathrm{sec}^{-1}$ (Zhu et al., 2005). Wittwer et al. (1990) suggested that the PCR yield increased when longer elongating time selected moreover, little change happened when the extension time was above 10 20 sec (Wittwer and Garling 1991). The extension time was only the transition time from the annealing step to the denaturation step in the study. If the optimal extension temperature was between 70 and $80^{\circ} \mathrm{C}$ and the extension could be negligible at other temperature, it took $3.33 \mathrm{sec}$ to go from $70-80^{\circ} \mathrm{C}$, using the Eppendorf Mastercycler with a heating rate of $3^{\circ} \mathrm{C} \mathrm{sec}^{-1}$. The average incorporating speed would be around $424 \mathrm{nt} \mathrm{sec}^{-1}$ $\left(1413 / 3.33 \mathrm{sec}^{-1}\right)$. Actually, the synthesis speed is not uniform, the greatest amplification capacity was far greater than the results reported previously (Hashimoto et al., 2004; Chen et al., 2008). This high amplification capacity might be the result of the specific kinetics of the polymerase but not the equipment or reagents used. The kinetics of the polymerase controls the length of fragment could be amplified. Therefore, further studies about the characteristics of Taq polymerase will improve the amplification potential of the two-temperature PCR.

The limitation of the knowledge influenced the exploring of the rapid PCR: $\mathrm{Mg}^{2+}$ influences enzyme activity and forms soluble complexes with dNTPs during DNA synthesis (Zippelius et al., 2000). As the concentration of 
$\mathrm{Mg}^{2+}$ increased, the dNTP incorporation and enzyme activity were enhanced while the sensitivity of the PCR reaction decreased and non-specific products were obtained when $\mathrm{Mg}^{2+}$ beyond $1.0 \mathrm{mmol} \mathrm{L}{ }^{-1}$. The optimal reaction conditions were affected by the presence of too many ions introduced by high concentrations of the Taq DNA polymerase and the result about the effects of different amount of polymerase were not consistent with other studies (Akane et al., 1994; Zippelius et al., 2000). The fact that the $1500 \mathrm{bp}$ fragment still could not be amplificated with this PCR even using the optimized two-temperature PCR system, implies that the kinetic activity of the polymerase was contributed to the inability of long fragments amplification in the two-temperature PCR.

Many studies showed that the extension rate is very limited (Angers et al., 2001; Sambrook and Russell, 2001), even in the most fast rate of $60.4 \mathrm{nt} \mathrm{sec}-1$ found before (Innis et al., 1988), the uniform extension rate was obtained in the optimal temperature interval during increasing form $70-80^{\circ} \mathrm{C}$ (Innis et al., 1988; Wittwer and Garling, 1991; Sambrook and Russell, 2001) and the heating rate of the cycler is about $2.5^{\circ} \mathrm{C} \mathrm{sec}^{-1}$, the extension length is only up to $241.6 \mathrm{bp}(60.4 \mathrm{nt} \mathrm{sec}-1$ $\left.\left(80-70^{\circ} \mathrm{C}\right) 2.5^{\circ} \mathrm{C} \mathrm{sec}{ }^{-1}\right)$. The comparison between theoretical and experiment yield of different length fragments showed that, the amplicon length is a key factor limiting the amplification of the long fragment and the longer fragments amplified, the lower extension rate obtained (Whitney et al., 2004). So, the studies on the rapid PCR later were focused on the special machines and the reagents. The studies about two-temperature PCR and the amplification capacity of the Taq polymerase were scarce. We obtained an extension rate at $424 \mathrm{nt} \mathrm{sec}-1$, helping to explore the kinetics of Taq polymerase deeply. The two-temperature PCR could be completed successfully using common Taq polymerases and equipment, the ramp time, between annealing step to denature step is enough to finish the extension for amplicons $\leq 1413$ bp. This evidence may be beneficial to researchers in any genetics laboratory. Using the two-temperature PCR program without the special reagents and equipment would save time and money costs.

Sex identification demonstrated the potential use of two-temperature PCR in more areas: The two-temperature PCR showed sufficient sensitivity in sex identification of cattle embryo using a single blastmere as the template and the false positive result was avoided. Furthermore, it greatly decreased the detection time, compared with the tedious PCR methods previously used
(Pomp et al., 1995; Tominaga and Hamada, 2004; Fu et al., 2007; Lu et al., 2007). Using common cycler, it took only 30-38 min to finish the amplification process with two-temperature PCR while this process lasted for $2 \mathrm{~h}$ using the common PCR program. More than two third of time was saved by two-temperature PCR and the detecting cost was decreased sharply.

\section{CONCLUSION}

A rapid, simple, efficient and cost-effective bovine sex identification method was established using a two-temperature PCR method that requires between 30 and $38 \mathrm{~min}$ for the amplification process. The two-temperature PCR which could be completed with common PCR reagents and equipment is the inherent reaction characteristic of Taq polymerases. The potential amplification ability could be greater and faster if the amplification properties of the Taq polymerase were better understood. The two-temperature PCR method is efficient in time and money, also of high sensitivity, simplicity and accuracy, it might contribute to the renovation of detection methods in many fields such as forensic medicine, clinical medicine and sex identification.

\section{ACKNOWLEDGEMENTS}

This research was supported by the National Natural Science Foundation of China (No. 30671502), the National $863 \mathrm{Hi}$-Tech Research and Development Program of China (No. 2006AA10Z143 and No. 2008AA101004) and National science and technology Support program of China (No. 2011BAD19B02).

\section{REFERENCES}

Akane, A., K. Matsubara, H. Nakamura, S. Takahashi and K. Kimura, 1994. Identification of the heme compound copurified with deoxyribonucleic acid (DNA) from blood stains, a major inhibitor of polymerase chain reaction (PCR) amplification. $\mathrm{J}$. Forensic Sci., 39: 362-372.

Angers, M., J.F. Cloutier, A. Castonguay and R. Drouin, 2001. Optimal conditions to use Pfu exo(-) DNA polymerase for highly efficient ligation-mediated polymerase chain reaction protocols. Nucleic Acids Res., 29: E83-E83.

Benter, T., S. Papadopoulos, M. Pape, M. Manns and H. Poliwoda, 1995. Optimization and reproducibility of random amplified polymorphic DNA in human. Anal. Biochem., 230: 92-100. 
Cha, R.S., H. Zarbl, P. Keohavong and W.G. Thilly, 1992. Mismatch amplification mutation assay (MAMA): Application to the c-H-ras gene. PCR Methods Appl., 2: 14-20.

Chen, P.C., D.E. Nikitopoulos, S.A. Soper and M.C. Murphy, 2008. Temperature distribution effects on micro-CFPCR performance. Biomed. Microdevices, 2: 141-152.

Easley, C.J., J.M. Karlinsey, J.M. Bienvenue, L.A. Legendre and M.G. Roper et al., 2006. A fully integrated microfluidic genetic analysis system with sample-in-answer-out capability. Proc. Natl. Acad. Sci., USA., 103: 19272-19277.

Ekici, H., N. Turan, B.H. Sontas, C.R. Helps, A. Senunver and H. Yilmaz, 2006. Sex determination of bovine embryos using poly-merase chain reaction (PCR). Revue. Med. Vet., 157: 441-444.

$\mathrm{Fu}$, Q., M. Zhang, W.S. Qin, Y.Q. Lu and H.Y. Zheng et al., 2007. Cloning the swamp buffalo SRY gene for embryo sexing with multiplex-nested PCR. Theriogenology, 68: 1211-1218.

Hashimoto, M., P.C. Chen, M.W. Mitchell, D.E. Nikitopoulos, S.A. Soper and M.C. Murphy, 2004. Rapid PCR in a continuous flow device. Lab. Chip, 4: 638-645.

Innis, M.A., K.B. Myambo, D.H. Gelfand and M.A. Brow, 1988. DNA sequencing with Thermus aquaticus DNA polymerase and direct sequencing of polymerase chain reaction-amplified DNA. Proc. Natl. Acad. Sci.USA., 85: 9436-9440.

Lam, W.Y., A.C. Yeung, J.W. Tang, M. Ip, E.W. Chan, M. Hui and P.K. Chan, 2007. Rapid multiplex nested PCR for detection of respiratory viruses. J. Clin. Microbiol., 45: 3631-3640.

Lu, W.F., N. Rawlings, J. Zhao and H. Wang, 2007. Amplification and application of the HMG box of bovine SRY gene for sex determination. Anim. Reprod. Sci., 100: 186-191.

Manna, L., G. Neglia, M. Marino, B. Gasparrini, R.D. Palo and L. Zicarelli, 2003. Sex determination of buffalo embryos (Bubalus bubalis) by polymerase chain reaction. Zygote, 11: 17-22.

Mapletoft, R.J. and J.F. Hasler, 2005. Assisted reproductive technologies in cattle: A review. Rev. Sci. Tech. Off. Int. Epiz., 24: 393-403.
Mullis, K.B. and F.A. Faloona, 1987. Specific synthesis of DNA in vitro via a polymerase-catalysed chain reaction. Methods Enzymol., 155: 335-350.

Pomp, D., B.A. Good, R.D. Geisert, C.J. Corbin and A.J. Conley, 1995. Sex identification in mammals with polymerase chain reaction and its use to examine sex effects on diameter of day-10 or -11 pig embryos. J. Anim. Sci., 5: 1408-1415.

Sambrook, J. and D.W. Russell, 2001. Molecular Cloning: A Laboratory Manual. 3rd Edn., Cold Spring Harbor Laboratory Press, New York, pp: 2100.

Tominaga, K. and Y. Hamada, 2004. Efficient production of sex-identified and cryosurvived bovine in-vitro produced blastocysts. Theriogenology, 61: 1181-1191.

Tominaga, K., 2004. Cryopreservation and sexing of in vivo- and in vitro-produced bovine embryos for their practical use. J. Reprod. Dev., 50: 29-38.

Wang, Y., D.E. Prosen, L. Mei, J.C. Sullivan, M. Finney and P.B.V. Horn, 2004. A novel strategy to engineer DNA polymerases for enhanced processivity and improved performance in vitro. Nucl. Acids Res., 32: 1197-1207.

Whitney, S.E., A. Sudhir, R.M. Nelson and H.J. Viljoen, 2004. Principles of rapid polymerase chain reactions: Mathematical modeling and experimental verification. Comput. Biol. Chem., 3: 195-209.

Wittwer, C.T. and D.J. Garling, 1991. Rapid cycle DNA amplification: Time and temperature optimization. Biotechniques, 10: 76-83.

Wittwer, C.T., G.C. Fillmore and D.J. Garling, 1990. Minimizing the time required for DNA amplification by efficient heat transfer to small samples. Anal. Biochem., 186: 328-331.

Zhang, Z.P., Y. Zhang, J.P. Liu, J.T. Zhang and Z.X. An et al., 2009. Codeposition of dNTPs detection for rapid LAMP-based sexing of bovine embryos. Reprod. Domestic Anim., 44: 116-121.

Zhu, H.B., D. Wang, J.H. Cheng, H.S. Hao, Z.L. Wang, B. Yang and Z.L. Wang, 2005. Study on fast sex determination of bovine pre-implantation embryos. Acta Veterinaria Zootechnica Sinica, 36: 1270-1274.

Zippelius, A., R. Lutterbuse, G. Riethmuller and K. Pantel, 2000. Analytical variables of reverse transcriptionpolymerase chain reaction-based detection of disseminated prostate cancer cells. Clin. Cancer Res., 6: $2741-2750$. 